\title{
DEBIT SEDIMEN MELAYANG DI SUNGAI KOMERING, KAYU AGUNG
}

\author{
Muizzaddin ${ }^{1}$, Netty Kurniawati², Sutopo $^{3}$ \\ 1muizzadin@student.pps.unsri.ac.id \\ 1,2,3Universitas Sriwijaya
}

\begin{abstract}
Sediment floating moving on the surface of the river. The amount of sediment was floated in an area can be used as a measure of the amount of sediment in the area. This study aimed to obtain sediment grain size, sediment concentration and debit sediment float. This study was conducted at three locations with twenty-seven sampling points. Based on the results of data processing used the method of screening, the dominant grain size between $(0,25 \mathrm{~mm}-0,125 \mathrm{~mm})$ with fine sand fraction. For the average value of sediment concentration, the largest at the center position amounted to $183.03 \mathrm{mg} / \mathrm{l}$ and the smallest on the left position amounted to $83.50 \mathrm{mg} / \mathrm{l}$. The floating of sediment debit found in 2 locations in the center position of 1802.73 tons/day and the smallest value in the location 2 in the left position amounted to 23874 tons / day.
\end{abstract}

Keywords: grain size, sediment floating

\begin{abstract}
ABSTRAK
Sedimen melayang merupakan sedimen yang bergerak melayang di atas permukaan dasar sungai. Besarnya sedimen melayang pada suatu daerah dapat digunakan sebagai tolak ukur besarnya sedimentasi pada daerah tersebut. Penelitian ini bertujuan untuk mendapatkan ukuran butir sedimen, konsentrasi sedimen dan debit sedimen melayang. Penelitian ini dilaksanakan di tiga lokasi dengan dua puluh tujuh titik pengambilan sampel. Berdasarkan hasil pengolahan data dengan mengunakan metode pengayakan, ukuran butir yang dominan diantara $(0,25 \mathrm{~mm}-0,125 \mathrm{~mm})$ dengan fraksi pasir halus. Untuk nilai rata-rata konsentrasi sedimen, terbesar pada posisi tengah sebesar $183.03 \mathrm{mg} / 1$ dan terkecil pada posisi kiri sebesar 83,50 mg/l. Debit sedimen melayang terbesar terdapat pada lokasi 2 di posisi tengah sebesar 1802,73 ton/ hari dan nilai terkecil dilokasi 2 pada posisi kiri sebesar 238,74 ton/hari.
\end{abstract}

Kata kunci: Ukuran butir, sedimen melayang.

\section{PENDAHULUAN}

Sungai merupakan saluran alamiah, yang mengalir dari dataran tinggi ke rendah. Aliran air tersebut akan membawa material-material yang berupa sedimen yang disebabkan oleh proses erosi pada hulu sungai yang kemudianterbawa oleh debit aliran sungai proses ini dapat menyebabkan terjadinya sedimentasi pada daerah hilir sungai, di mana aliran air tersebut akan bermuara (Mokonio et al., 2013).

Daerah Aliran Sungai (DAS) dapat diartikan sebagai ekosistem, maka setiap ada masukan berupa curah hujan ke dalam ekosistem tersebut akan menghasilkan keluaran (output) berupa debit, muatan sedimen dan material lainnya yang terbawa oleh aliran sungai (Asdak, 2001).

Sungai Komering mempunyai peranan yang penting sebagai jalur transportasi umum bagi aktifitas ekonomi masyarakat yang berada disepanjang sungai.Daerah muara Sungai Komering juga merupakan daerah yang mengalami proses sedimentasi yang cukup tinggi karena bermuaranya 
berbagai sungai yang membawa sedimen. Perairan Sungai Komering memiliki kedalaman yang bervariasi. Morfologi perairan terutama dibentuk oleh hasil endapan sedimen dari sungai dengan sebaran yang dikontrol oleh aktifitas aliran arus sungai dan arus memiliki pengaruh yang besar terhadap pola pergerakan sedimen.

Potensi Besarnya sedimentasi dapat diketahui dengan menentukan besarnya nilai konsentrasi sedimen tersuspensi di wilayah tersebut. Debit aliran sungai akan mengangkut sedimen yang tersuspensi di sungai, ketika menuju laut dipengaruhi oleh besarnya kecepatan arus.

Poerbandono dan Djunarsjah (2005) menyatakan, sedimen yang berukuran lebih kecil cenderung terbawa suspensi yang mengikuti kecepatan dan arah arus. Oleh karena ituperlu dilakukan penelitian untuk mengetahui kondisi dari Daerah Aliran Sungai (DAS)Komering sehingga dapat memberikan informasi mengenai angkutan sedimen melayang yang ada pada daerah tersebut.

\section{METODE PENELITIAN}

Penelitian ini dilaksanakan pada bulan Febuari 2016 sampai dengan selesai. Pengambilan sampel berupa sedimen melayang dilakukan pada 3 (tiga) lokasi dengan 27 titik pengamatan di daerah aliran sungai Komering. Adapun pengolahan data di Laboratorium Dinas Pertambangan dan Energi di Palembang serta Laboratorium Geofisika, Jurusan Fisika, Fakultas Matematika dan Ilmu Pengetahuan Alam, Universitas Sriwijaya.

Alat yang digunakan dalam penelitian adalah alumunium foil, compas, CTD, current meter, ekman Grab, GPS dan timbangan analitik. Bahan yang dibutuhkan dalam penelitian ini air sungai dan sedimen.
Pengukuran sampel konsentrasi sedimen dilakukan di Laboratorium Dinas Pertambangan Kota Palembang dengan tahapan sebagai berikut:

1. Menyiapkan kertas saring kosong yang telah ditimbang.

2. Kemudian sampel (air yang mengadung sedimen) dikocok hingga merata dan memasukan $100 \mathrm{ml}$ sampel ke dalam alat penyaring.

3. Angkat kertas saring yang telah selesai menyaring.

4. Mengeringkan kertas saring isi di dalam oven dengan suhu 103-105 C.

5. Dinginkan kertas saring selama 5 menit.

6. Kemudian timbang kertas yang telah isi dengan neraca analitik.

\section{HASIL DAN PEMBAHASAN \\ Lebar dan Kedalaman Sungai}

Penelitian ini dilaksanakan di Sungai Komering, sub DAS Musi dengan jumlah stasiun pengamatan sebanyak 27 titik dan terbagi menjadi tiga lokasi yaitu Lokasi pertama terletak dibagian hutan, lokasi kedua dibagian pemukiman dan lokasi ketiga terletak didaerah pemukiman. Masing-masing lokasi terdiri dari 9 titik stasiun dan terbagi menjadi 3 posisi kanan, tengah dan kiri.

Nilai pengukuran lebar dan kedalaman sungai merupakan data yang diperlukan untuk menghitung besarnya debit aliran sungai, nilai pengukuran lebar sungai dan kedalaman sungai (Tabel 1).

Tabel 1, lebar sungai komering sangat bervariasi pada setiap lokasi. Sungai yang memiliki lebar terbesar yaitu pada Stasiun 1.1 dengan lebar 105 meter, sedangkan sungai terkecil terletak pada Stasiun 2.3 dengan lebar yaitu 48 meter. Pada Stasiun 1.2 dan 1.3 memiliki lebar yang hampir sama diantara 80-85 meter, sedangkan pada Stasiun 2.1 dan 2.2 memiliki perbandingan lebar sungai yang 
cukup besar yakni untuk lokasi 2.1 dengan lebar sungai 70 meter, sedangkan Stasiun 2.3 memiliki lebar sungai 85 meter. Stasiun 3.1 dan 3.2 memiliki lebar sungai yang hampir sama yakni 74 meter, sedangkan Stasiun 3.3 memiliki lebar sungai yang lebih besar dari Stasiun 3.1 dan 3.2, yakni dengan lebar sungai 79 meter.

Sungai komering memiliki kedalaman yang bervariasi di masingmasing Stasiun pada Lokasi 1, kedalaman sungai pada posisi tengah memiliki nilai yang paling besar yakni dengan rata-rata kedalaman sungai 4 meter, sedangkan posisi kanan dan kiri memiliki kedalaman 2 meter. Lokasi 2 memiliki kedalaman sungai terbesar, pada posisi tengah dengan rata-rata kedalaman sungai yakni 16 meter, sedangkan posisi kanan memiliki kedalaman 7 meter, dan posisi kiri memiliki kedalam 5 meter. Lokasi 3 hampir memiliki kedalaman yang sama yakni berkisar antara 70-79 meter pada setiap posisi pengambilan sampel.

\section{Debit Aliran Sungai}

Nilai debit aliran sungai dibutuhkan untuk memperoleh nilai debit sedimen melayang. Nilai debit aliran sungai diperoleh dengan cara perhitungan dengan menggunakan persamaan sehingga di dapat hasil (Tabel 2), (Rahayuet al.,2009).

Hasil pengukuran di daerah aliran sungai komering terlihat bahwa adanya variasi debit yang terjadi pada masingmasing titik pengambilan sampel. Lokasi 1 posisi tengah memiliki nilai debit terbesar rata-rata nilai $81.21 \mathrm{~m} 3 /$ detik, sedangkan pada posisi kanan memiliki nilai $61.25 \mathrm{~m} 3 /$ detik, dan kiri memiliki nilai debit $56.29 \mathrm{~m} 3 /$ detik. Lokasi 2 posisi tengah juga memiliki nilai debit yang terbesar yakni dengan nilai 73.31m3/detik, sedangkan pada posisi kanan memiliki nilai debit 39.67m3/detik, sedangkan pada posisi kiri memiliki nilai 30.92m3/detik. Lokasi 3 posisi kanan memiliki nilai rata-rata debit terbesar yaitu dengan nilai 33.65m3/detik, posisi tengah dan 27.50 $\mathrm{m} 3 /$ detik, pada posisi kiri memiliki nilai $30.29 \mathrm{~m} 3 /$ detik. Debit sungai yang besar akan mempengaruhi pola sirkulasi arus sungai komering. Hal ini terlihat dari besarnya debit yang terjadi melalui sungai, dengan debit yang besar maka akan mendorong pergerakan angkutan sedimen ke arah sungai musi yang relatif lebih tinggi.

\section{Konsentrasi Sedimen}

Nilai konsentrasi sedimen didapat dari data lapangan dan data Laboratorium Dinas Pertambangan Kota Palembang, Nilai konsentrasi sedimen (Tabel 3).

Berdasarkan hasil analisa yang dilakukan di Laboratorium Dinas Pertambangan Kota Palembang, telah diperoleh nilai konsentrasi sedimen (Csi) yang bervariasi dari masing-masing titik pengambilan sampel. Menurut Tchobanoglous and Burton (1991); (Effendi, 2003), komposisi limbah cair kegiatan domestik untuk parameter padatan tersuspensi (melayang) dengan konsentrasi $350 \mathrm{mg} / 1$ termasuk kategori berat, $200 \mathrm{mg} / 1$ termasuk kategori sedang dan 100 mg/l kategori ringan.

Rata-rata nilai konsentrasi sedimen yang diperoleh untuk Lokasi I pada posisi kanan sebesar 55,7 mg/l, pada posisi tengah $43,3 \mathrm{mg} / 1$ dan pada posisi kiri 53,3 mg/l. Hal ini meunjukkan bahwa ukuran butir sedimen melayang termasuk dalam katagori ringan.

Pada Lokasi 2, untuk posisi kanan memiliki nilai konsentrasi sedimen yaitu sebesar $83 \mathrm{mg} / 1$. 
Tabel 1. Nilai Lebar dan Kedalaman Sungai Komering

\begin{tabular}{ccccccc}
\hline \multirow{2}{*}{ Lokasi } & \multicolumn{3}{c}{ Lebar Sungai $(\mathbf{m})$} & \multicolumn{3}{c}{ Kedalaman sungai $(\mathbf{m})$} \\
\cline { 2 - 7 } & Kanan & Tengah & Kiri & Kanan & Tengah & Kiri \\
\hline 1.1 & 35.20 & 35.20 & 35.20 & 1.80 & 3.49 & 2.10 \\
1.2 & 28.48 & 28.48 & 28.48 & 1.01 & 4.54 & 2.78 \\
1.3 & 28.06 & 28.06 & 28.06 & 3.56 & 3.99 & 2.29 \\
Rata-rata & & & & 2.12 & $\mathbf{4 . 0 1}$ & $\mathbf{2 . 3 9}$ \\
2.1 & 23.64 & 23.64 & 23.64 & 2.02 & 4.62 & 1.62 \\
2.2 & 28.64 & 28.64 & 28.64 & 2.70 & 5.35 & 1.77 \\
2.3 & 16.26 & 16.26 & 16.26 & 2.89 & 6.96 & 2.41 \\
Rata-rata & & & & 2.54 & $\mathbf{5 . 6 4}$ & $\mathbf{1 . 9 3}$ \\
3.1 & 24.92 & 24.92 & 24.92 & 4.67 & 2.38 & 4.22 \\
3.2 & 24.69 & 24.69 & 24.69 & 1.88 & 2.51 & 2.66 \\
3.3 & 26.55 & 26.55 & 26.55 & 1.40 & 3.65 & 2.03 \\
Rata-rata & & & & 2.65 & $\mathbf{2 . 8 5}$ & $\mathbf{2 . 9 7}$ \\
\hline
\end{tabular}

Sumber: Hasil penelitian, 2016

Tabel 2 Nilai Debit Sungai Komering

\begin{tabular}{cccccccccc}
\hline \multirow{2}{*}{ Lokasi } & \multicolumn{3}{c}{ Luas penampang $\left(\mathbf{m}^{2}\right)$} & \multicolumn{3}{c}{ Kecepataan arus $(\mathbf{m} / \mathbf{s})$} & \multicolumn{3}{c}{ Debit Aliran Sungai $\left(\mathbf{m}^{3} / \mathbf{s}\right)$} \\
\cline { 2 - 7 } & Kanan & Tengah & Kiri & Kanan & Tengah & Kiri & Kanan & Tengah & Kiri \\
\hline 1.1 & 93.27 & 123.18 & 98.69 & 0.75 & 1.00 & 0.33 & 70.33 & 123.58 & 33.38 \\
1.2 & 79.87 & 129.54 & 104.40 & 0.47 & 0.59 & 0.54 & 44.36 & 77.05 & 57.14 \\
1.3 & 106.06 & 111.99 & 88.21 & 0.65 & 0.38 & 0.88 & 69.07 & 43.00 & 78.35 \\
Rata-rata & & & & 0.21 & 0.66 & 0.59 & 61.25 & 81.21 & 56.29 \\
2.1 & 61.28 & 109.26 & 73.78 & 0.51 & 0.59 & 0.63 & 31.53 & 65.32 & 47.07 \\
2.2 & 115.41 & 153.45 & 102.20 & 0.30 & 0.64 & 0.13 & 35.17 & 98.58 & 14.17 \\
2.3 & 80.20 & 113.30 & 76.31 & 0.65 & 0.49 & 0.41 & 52.31 & 56.04 & 31.52 \\
Rata-rata & & & & 0.49 & 0.57 & 0.39 & 39.67 & 73.31 & 30.92 \\
3.1 & 145.17 & 59.49 & 128.36 & 0.30 & 0.17 & 0.40 & 43.69 & 10.65 & 52.54 \\
3.2 & 54.31 & 62.07 & 67.58 & 0.20 & 0.38 & 0.38 & 11.14 & 23.79 & 25.81 \\
3.3 & 67.26 & 97.18 & 75.62 & 0.68 & 0.49 & 0.163 & 46.12 & 48.06 & 12.32 \\
Rata-rata & & & & 0.39 & 0.35 & 0.31 & 33.65 & 27.50 & 30.22 \\
\hline
\end{tabular}

Sumber: Hasil penelitian, 2016.

Tabel 3. Konsentrasi Sedimen

\begin{tabular}{|c|c|c|c|c|c|c|c|c|c|c|}
\hline \multirow[t]{2}{*}{ Lokasi } & \multicolumn{3}{|c|}{ Berat Kertas saring Kosong (g) } & \multicolumn{3}{|c|}{$\begin{array}{l}\text { Berat Kertas saring isi } \\
\text { Sedimen }(\mathrm{g})\end{array}$} & \multirow[t]{2}{*}{ Volume air (1) } & \multicolumn{3}{|c|}{ Konsetrasi Sedimen $(\mathrm{mg} / \mathrm{l})$} \\
\hline & Kanan & Tengah & Kiri & Kanan & Tengah & Kiri & & Kanan & Tengah & Kiri \\
\hline 1.1 & 0.1690 & 0.1612 & 0.1671 & 0.1733 & 0.1629 & 0.1679 & 0.1 & 43 & 17 & 8 \\
\hline 1.2 & 0.1661 & 0.1612 & 0.1691 & 0.1781 & 0.1665 & 0.1824 & 0.1 & 120 & 16 & 133 \\
\hline 1.3 & 0.1676 & 0.1660 & 0.1683 & 0.1680 & 0.1757 & 0.1702 & 0.1 & 4 & 97 & 19 \\
\hline \multicolumn{8}{|c|}{ Rata-rata } & 55.67 & 43.33 & 53.33 \\
\hline 2.1 & 0.1668 & 0.1672 & 0.1678 & 0.1682 & 0.2085 & 0.1707 & 0.1 & 14 & 413 & 29 \\
\hline 2.2 & 0.1616 & 0.1664 & 0.1667 & 0.1680 & 0.1672 & 0.1707 & 0.1 & 64 & 8 & 40 \\
\hline 2.3 & 0.1628 & 0.1628 & 0.1636 & 0.1835 & 0.1660 & 0.1659 & 0.1 & 171 & 32 & 23 \\
\hline \multicolumn{8}{|c|}{ Rata-rata } & 83 & 252 & 30.67 \\
\hline 3.1 & 0.1684 & 0.1682 & 0.1695 & 0.1782 & 0.1703 & 0.1698 & 0.1 & 98 & 21 & 3 \\
\hline 3.2 & 0.1667 & 0.1638 & 0.1687 & 0.1765 & 0.1660 & 0.1903 & 0.1 & 98 & 22 & 216 \\
\hline 3.3 & 0.1678 & 0.1678 & 0.1659 & 0.1702 & 0.1862 & 0.1834 & 0.1 & 24 & 184 & 175 \\
\hline \multicolumn{8}{|c|}{ Rata-rata } & 73.33 & 75.67 & 131.33 \\
\hline
\end{tabular}

Sumber: Hasil penelitian, 2016. 
Sedangkan pada posisi tengah 151 $\mathrm{mg} / \mathrm{l}$, dan pada posisi kiri 30,7 mg/1, hal ini menjukkan bahwa konsentrasi sedimen pada Lokasi 1 tergolong dalam katagori ringan, sedangkan pada Lokasi 3 untuk posisi kanan memiliki nilai konsentrasi sedimen sebesar 73,3 mg/l, sedangkan pada posisi tengah yaitu 75,7 $\mathrm{mg} / \mathrm{l}$, dan posisi kiri yaitu dengan nilai 131,3, hal ini juga menunjukkan bahwa Lokasi 3 termasuk dalam kategori ringan.

\section{Debit Sedimen Melayang}

Nilai debit sedimen melayang diperoleh dari hasil perhitungan dengan persamaan qs=0,0864.C.Q dengan $C$ merupakan konsentrasi sedimen $(\mathrm{mg} / \mathrm{l})$ dan $Q$ merupakan debit sungai (m3/d), hasilnya (Tabel 4), (Hidayah et al., 2013).

Tabel 4 menunjukkan nilai debit sedimen melayang pada setiap lokasi berbeda-beda apabila di rata-rata kan setiap lokasi pada titik yang sama. Pada Lokasi 1 pada posisi kanan memiliki nilai debit sedimen melayang sebesar 227,27ton/hari, sedankan pada posisi tengah memiliki nilai 216,15ton/hari, dan pada posisi kiri memiliki nilai 269,46 ton/hari. Lokasi 2, untuk posisi kanan memiliki nilai debit sedimen melayang 335,20ton/hari, sedangkan pada posisi tengah memiliki nilai 851,38ton/hari, dan pada posisi kiri memiliki nilai 76,52ton/hari. Lokasi 3 debit sedimen melayang paling besar terletak pada posisi kanan dengan rata-rata nilai debit sedimen melayang yaitu sebesar 276,23ton/hari, sedangkan pada posisi tengah memiliki nilai 227,26 ton/hari dan pada posisi kiri memiliki nilai 186,67 ton/hari.

\section{Analisa Ukuran Butir}

Ukuran butiran sedimen merupakan hal yang penting untuk mempelajari proses sedimentasi untuk menganalisa ukuran butiran sedimen dapat ditentukan dengan kisaran (range) ukuran butir sampel sedimen, dalam pengukuran sedimen yang diukur diameter. Diameter sedimen didefenisikan dengan menggunakan skala phi dengan klasifikasi ukuran butir menggunakan phi-2 sampai +5 yang di interpretasi bahwa butiran tersebut berupa krikil sampai lumpur sedang (Tabel 5), dalam penelitian ini untuk menentukan ukuran butir sedimen dilakukan dengan saringan bertingkat.

Hasil analisa sampel sedimen di sungai komering medapatkan tiga fraksi sedimen yang berada pada daerah aliran sungai tersebut yaitu fraksi krikil, pasir, dan lumpur yang memiliki nilai pesentase berbeda-beda pada setiap stasiun.

Tabel 4. Nilai Debit Sedimen Melayang

\begin{tabular}{cccc}
\hline \multirow{2}{*}{ Lokasi } & \multicolumn{3}{c}{ Debit Sedimen Melayang (ton/hari) } \\
\cline { 2 - 4 } & Kanan & Tengah & Kiri \\
\hline 1.1 & 261.29 & 181.52 & 23.07 \\
1.2 & 396.67 & 106.52 & 656.68 \\
1.3 & 23.87 & 360.41 & 128.63 \\
Rata-rata & 227.27 & 216.15 & 269.46 \\
2.1 & 38.14 & 2331.08 & 117.94 \\
2.2 & 194.48 & 68.13 & 48.98 \\
2.3 & 772.99 & 154.94 & 62.63 \\
Rata-rata & 335.20 & 851.38 & 76.52 \\
3.1 & 369.98 & 19.32 & 13.61 \\
3.2 & 94.40 & 45.22 & 481.78 \\
3.3 & 95.63 & 764.15 & 186.39 \\
Rata-rata & 186.67 & 276.23 & 227.26 \\
\hline
\end{tabular}


Tabel 5. Skala Ukuran Butir

\begin{tabular}{ccc}
\hline Wentworth $(\mathbf{m m})$ & Phi & Keterangan Fraksi \\
\hline 4 & -2 & Kerikil \\
2 & -1 & Butiran \\
1 & 0 & Pasir sangat kasar \\
0,5 & 1 & Pasir kasar \\
0,25 & 2 & Pasir sedang \\
0,125 & 3 & Pasir halus \\
0,063 & 4 & Pasir sangat halus \\
0,038 & 5 & Lumpur kasar \\
-0.038 & $>5$ & Lumpur sdang \\
\hline
\end{tabular}

Sumber: https://geohazard009.wordpress.com/2009/10/20/skala-wentworth/

Secara umum jenis sedimen yang dominan pada tiga daerah tersebut adalah pasir halus $(0,25 \mathrm{~mm}-0,125 \mathrm{~mm})$ dan dapat kita lihat pada Lampiran Persentasi Fraksi Sedimen.

Berdasarkan analisa secara umum ukuran butir sedimen pada lokasi kanan, tengah dan kiri berbeda-beda, pada lokasi kanan dan kiri didominasi fraksi pasir halus, sedangkan pada lokasi tengah didomenasi fraksi pasir sedang. Hal ini disebabkan oleh kondisi lingkungan dan kecepatan arus sungai, dimana pada lokasi kanan dan kiri terdapat banyak tanaman eceng gondok sehingga kecepatan arus relativ lebih kecil, sedangkan pada lokasi tegah memiliki kecepataan arus yang besar karena tidak terdapat eceng gondok atau penghalang pergerakaan arus. Kecepatan arus sangat mempengaruhi pergerakan ukuran butir sedimen. Semakin besar arus sungai maka semakin besar ukuran butir sedimen dan semakin kecil kecepataan arus maka semakin kecil ukuran yang bergerak terbawah oleh arus.

\section{Hubungan Debit Sedimen Melayang Terhadap Lokasi Penelitian}

Debit sedimen melayang merupakan faktor untuk menentukan besar kecilnnya proses sedimentasi pada suatu sungai, debit sedimen melayang dapat bergerak disepanjang aliran sungai tergantung pada komposisi (ukuran dan berat kondisi aliran (kecepatan aliran, keadaan aliran). Pengaruh sedimen dalam aliran sungai dapat menggangu ekosistem perairan. Untuk gambaran yang lebih jelas, dapat dilihat pada gambar 1.

Gambar 1 merupakan grafik yang menujukkan hubunganantara debit sedimen melayang terhadap Lokasi penelitian pada Lokasi 1 untuk titik 1.1 posisi kanan mengalami kenaikan debit sedimen melayang pada titik Lokasi 1.2 sedangkan pada titik Lokasi 1.3 debit sedimen melayang mengalami penurunan, hal ini disebabakan oleh beberapa faktor seperti besarnya konsentrasi sedimen, pada daerah tersebut, lingkungan adanya kerambah ikan dan posisi pengambilan sampel sedimen dimana pada posisi titik Lokasi 1.2 kiri berada pada tikungan sungai dan terdapat percabangan sungai yang menyebabkan debit sedimen melayang naik dan sebaliknya pada titik Lokasi 1.3 konsentrasi sedimen relatif lebih kecil.

Lokasi 1 posisi tengah mengalami kenaikan debit sedimen melayang pada titik Lokasi 1.3 sedangkan pada titik Lokasi 1.2 debit sedimen melayang mengalami penurunan, hal ini disebabakan oleh beberapa faktor seperti 
besarnya konsentrasi sedimen pada Lokasi tersebut dan lingkungan dimana pada posisi tengah tidak adanya pengaruh tanaman air dan posisi pengambilan sampel sedimen dimana pada posisi titik Lokasi 1.3 kiri berada pada tikungan sungai.

Lokasi 1 posisi kiri mengalami kenaikan debit sedimen melayang pada titik Lokasi 1.2 sedangkan pada titik Lokasi 1.3 debit sedimen melayang mengalami penurunan, hal ini disebabakan oleh faktor konsentrasi sedimen besar, lingkungan dan posisi pengambilan sampel sedimen dimana pada posisi titik Lokasi 1.2 kiriberada pada tikungan sungai yang menyebabkan debit sedimen melayang naik dikarenakan pada posisi tikungan kecepetaan arus relatif lebih besar.

Gambar 2 menunjukkan hubungan antara debit sedimen melayang terhadap Lokasi penelitian pada Lokasi 2 untuk titik 2.1 posisi kanan mengalami kenaikan debit sedimen melayang pada titik Lokasi 2.2 dan Lokasi 2.3, hal ini disebabkan oleh beberapa faktor seperti besarnya konsentrasi sedimen pada daerah tersebut, lingkungan adanya kerambah ikan dan posisi pengambilan sampel sedimen dimana pada posisi titik Lokasi 2.3 kiri berada pada pemukiman penduduk yang banyak aktivitas manusia pada aliran sungai tersebut seperti adanya kerambah ikan yang menyebabkan sedimen yang berada pada daerah tersebut lebih banyak.

Lokasi 2 posisi tengah mengalami kenaikan debit sedimen melayang pada titik Lokasi 2.3 sedangkan pada titik Lokasi 2.2 debit sedimen melayang mengalami penurunan, hal ini disebabakan oleh beberapa faktor seperti kecilnya konsentrasi sedimen pada Lokasi 2.2, lingkungan dan posisi pengambilan sampel sedimen dimana pada posisi titik Lokasi 2.3 kiri berada pada pemukiman penduduk dan terdapat banyak aktivitas manusia di daerah aliran sungai yang menyebabkan debit sedimen melayang mengalami kenaikan.

Lokasi 2 posisi kiri yang mengalami kenaikan debit sedimen melayang yaitu pada titik Lokasi 2.1 sedangkan pada titik Lokasi 2.2 debit sedimen melayang mengalami penurunan, hal ini disebabakan oleh beberapa faktor seperti besarnya konsentrasi sedimen, lingkungan dan posisi pengambilan sampel sedimen dimana pada posisi titik Lokasi 2.1 kiri berada pada tikungan sungai yang menyebabkan debit sedimen melayang naik.

Gambar 3 menujukkan bahwa hubungan antara debit sedimen melayang terhadap Lokasi penelitian. Pada Lokasi 3 untuk titik 3.1 sampai titik Lokasi 3.3 posisi kanan mengalami penurunan debit sedimen melayang. Hal ini disebabakan oleh beberapa faktor seperti, kecilnya nilai konsentrasi sedimen pada daerah tersebut, dan posisi pengambilan sampel sedimen, dimana pada posisi titik Lokasi 3.3 kanan berada di hutan.

Lokasi 3, untuk titik Lokasi 3.1 posisi tengah mengalami kenaikan debit sedimen melayang pada titik Lokasi 3.3, hal ini disebabakan oleh beberapa faktor seperti besarnya konsentrasi sedimen, lingkungan dimana pada posisi titik Lokasi 3.3 pada posisi tengah, tidak adanya pengaruh lingkungan seperti adanya tanaman eceng gondok atau tanaman lainya yang mempengaruhi laju sedimen.

Pada Lokasi 3 posisi kiri mengalami penurunan debit sedimen melayang, yang terjadi pada titik Lokasi 3.1 sampai titik Lokasi 3.3, hal ini disebabakan oleh faktor seperti konsentrasi sedimen yang semakin kecil ke hilir, dan posisi pengambilan sampel yang berada pada daerah hutan dan tidak terdapat banyak aktivitas manusia dipingiran sungai. 


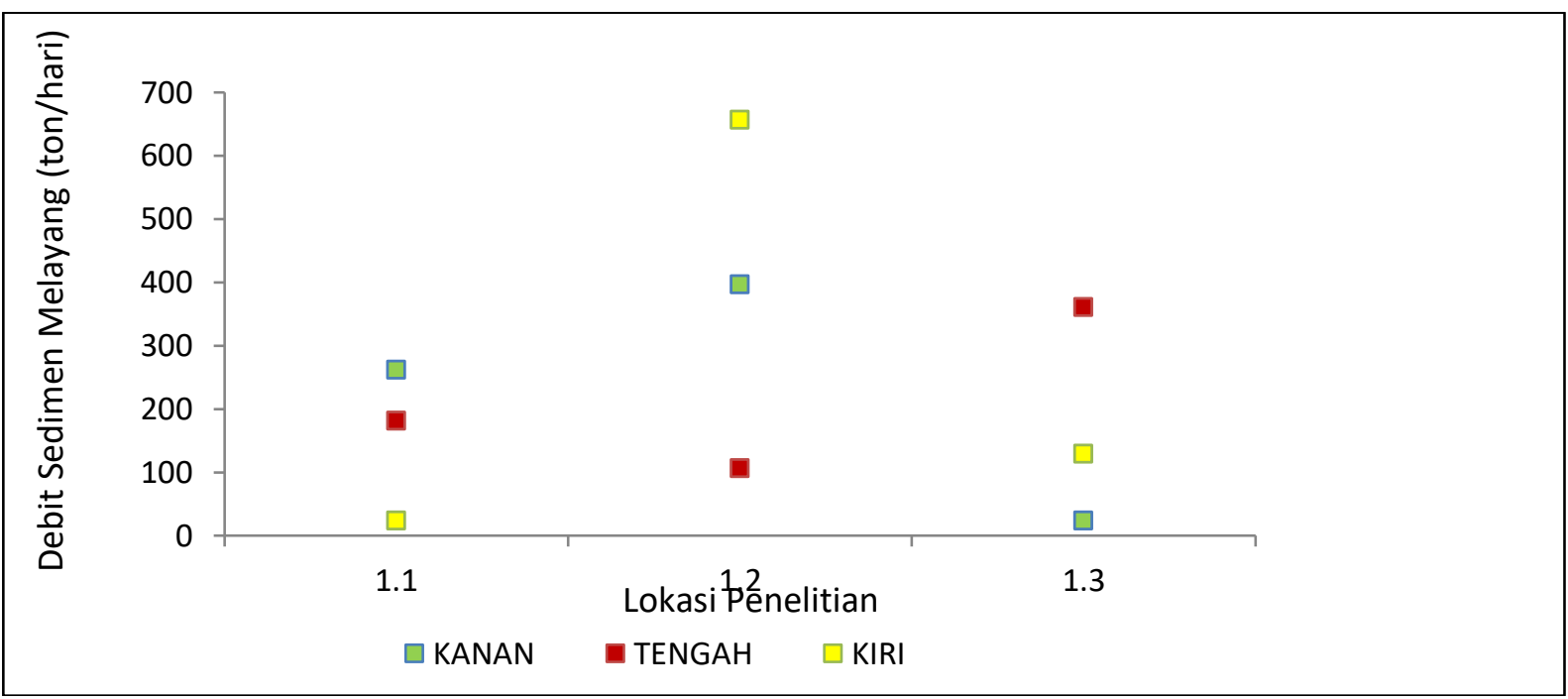

Gambar 1. Grafik hubungan Debit Sedimen Melayangterhadap Lokasi Penelitian

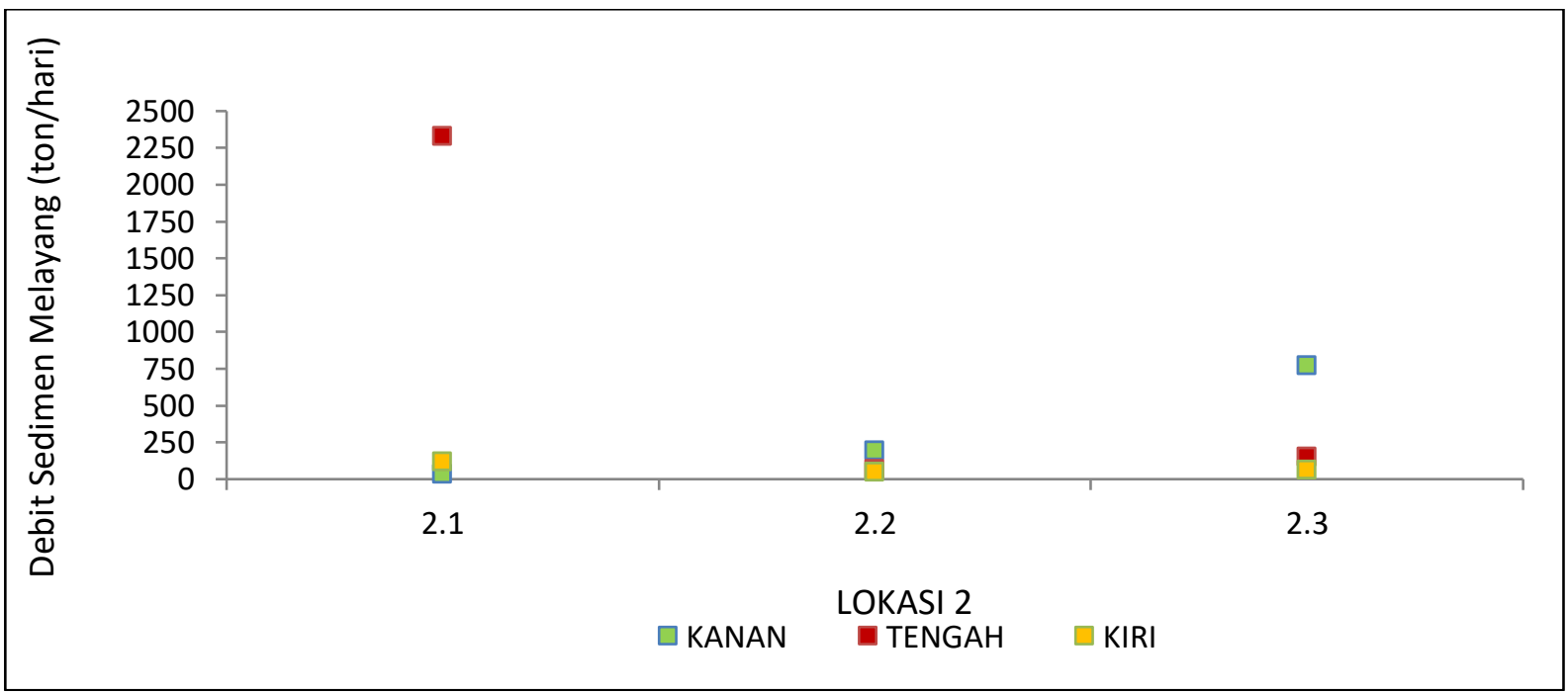

Gambar 2. Grafik hubungan Debit Sedimen Melayangterhadap Lokasi penelitian

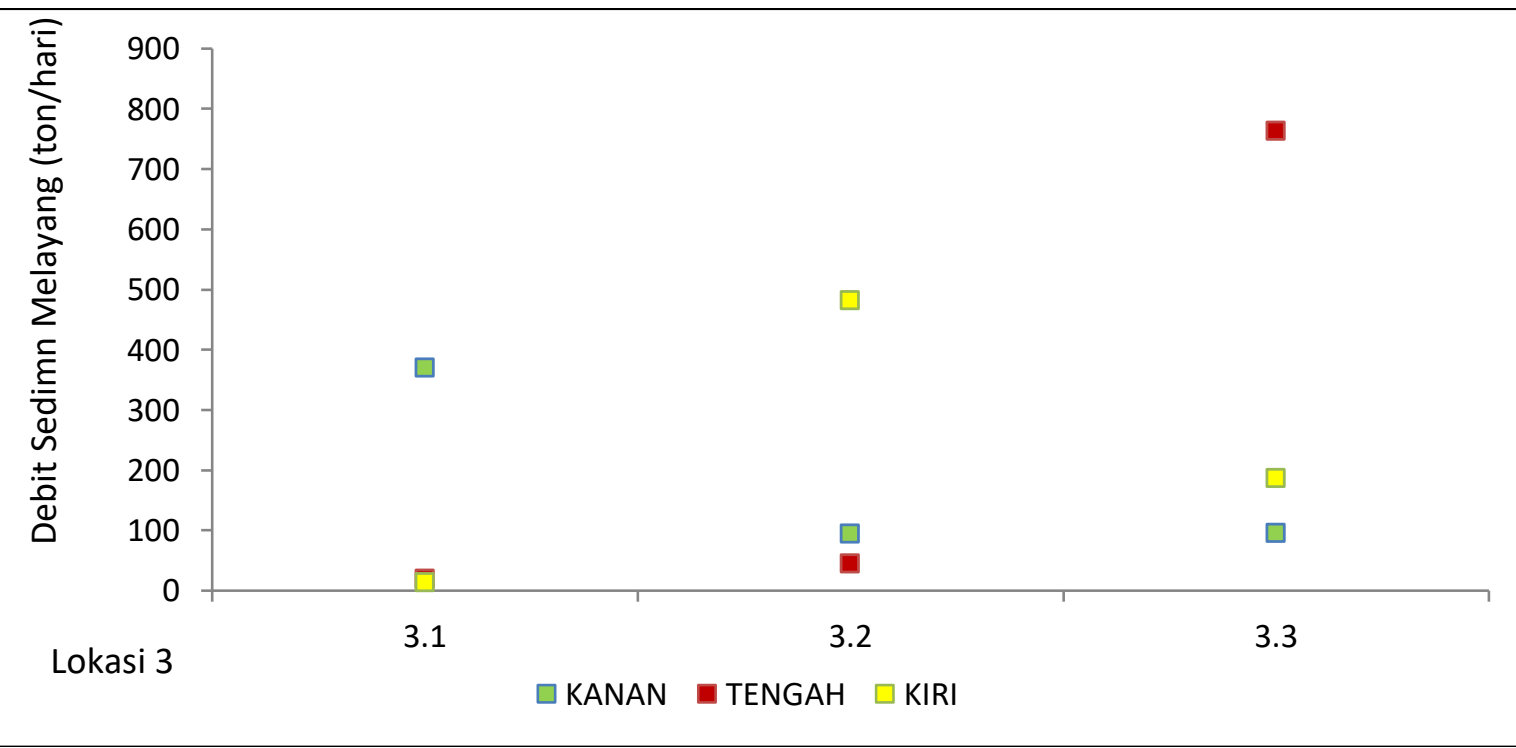

Gambar 3. Grafik hubungan Debit Sedimen Melayang terhadap Lokasi Penelitian 


\section{SIMPULAN}

Fraksi Sedimen muatan dasar pada setiap stasiun pengambilan sampel terdiri dari kerikil, pasir dan lumpur. Secara umum sedimen yang dominan adalah pasir halus $(0,25 \mathrm{~mm}-0.125)$. Konsentrasi sedimen memiliki nilai rata-rata terbesar terletak pada Lokasi 2 posisi tengah dengan nilai $52 \mathrm{mg} / 1$ dan nilai konsentrasi sedimen terkecil pada Lokasi 2 posisi kiri dengan nilai sebesar 30,67 $\mathrm{mg} /$.Debit sedimen melayang memiliki nilai rata-rata terbesar terletak pada Lokasi 2 sebesar 851.3889 ton/hari di posisi tengah. Sedangkan nilai debit sedimen terkecil pada Lokasi posisi kiri sebesar 76.5217 ton/hari.

\section{DAFTAR PUSTAKA}

Asdak, C. (2004). Hidrologi dan Pengelolaan Daerah Aliran Sungai.Gadjah Mada University Press. Yogyakarta.

Effendi, H. (2003). Telaah Kualitas Air Bagi Pengelolahan Sumber Daya dan Lingkungan Perairan. Yogyakarta: Kanisius. Halaman 168169 tersedia di https://books. google.co.id/books?id=HyjDhfW87 B0C\&sitesec $=$ buy\&hl $=\mathrm{id} \&$ source $=\mathrm{g}$ bs_vpt_read

Hidayat, N, Y, N., Suprapto, M., dan Suryanto. (2013). Kajian Angkutan Sedimen Pada Sungai Begawan Solo
(Serena-Jurug). E-Jurnal Matrik Teknik Sipil. 69-73 hlm tersedia di http://sipil.ft.uns.ac.id/ojsin/index .php/MaTekSi/about

Mokonio, O., Mananoina, T., Tanudjaja, L., dan Bininglang, A. (2013). Analisis Sedimentasi di Muara Sungai Saluwangko di Desa Tounelet Kecamatan Kakas Kabupaten Minahasa.Jurnal Sipil Statik 6 (1) :452-458.tersedia di https://ejournal.unsrat.ac.id/index. php/jss/article/view/1438

Poerbandono dan E. Djunarsjah. (2005). Survey Hidrograf. Refika Aditama, Bandung

Rahayu, S., Harto, W, R., Van, N, M., Suryadi, I., dan Verbist, B. (2009). Monitoring air di daerah aliran sungai. Bogor, Indonesia. World Agroforestry Centre - Southeast Asia Regional Office: +104.tersedia di https://www.worldagroforestry. org/publication/monitoring-air-didaerah-aliran-sungai

Wordpress (online), skalah wentworth, tersedia di https://geohazard009. wordpress.com/2009/10/20/skalawentworth/ diakses pada 27 September 2016. 